\title{
ASSOCIATION OF BLOOD LEAD LEVEL WITH \\ CLINICAL AND RENAL PARAMETERS IN A GROUP OF EGYPTIAN LEAD EXPOSED WORKERS
}

\author{
By \\ ${ }^{1}$ Gadallah MA, ${ }^{1}$ Hakim SA and ${ }^{2}$ Mohsen A \\ ${ }^{1}$ Department of Community, Occupational and Environmental Medicine, Faculty of Medicine, \\ Ain Shams University, ${ }^{2}$ Department of Community Medicine, National Research Centre, Cairo, Egypt.
}

\begin{abstract}
Introduction: Occupational lead exposure increases the risk for adverse renal outcomes. Lead has been reported to cause nephrotoxicity by several mechanisms. Moreover, lead toxicity induces various effects on many organs. Aim of Work: to study the association between blood lead level and some renal and clinical parameters among workers exposed to lead. Materials and Methods: The study included 120 lead exposed workers (galvanic painting) seeking periodic medical examination. The workers answered a questionnaire including questions regarding their socio-demographic characteristics and medical complaints. Also, a blood sample was withdrawn for measuring blood lead level, serum creatinine, serum uric acid and blood urea. Results: The percentage of workers with blood lead level $\geq 20$ microgram/dl $(\mu \mathrm{g} / \mathrm{dl})$ presenting with abdominal pain, tremors and tingling of the extremities was significantly higher than the percentage of workers with blood lead level less than $20 \mu \mathrm{g} / \mathrm{dl}$ reporting the same symptoms. Moreover, the mean serum uric acid was significantly higher among workers with blood lead level $\geq 20 \mu \mathrm{g} / \mathrm{dl}$ than among those with blood lead level less than $20 \mu \mathrm{g} / \mathrm{dl}$. Conclusion: Lead exposed workers are at risk of several system affection including the kidneys. This necessitates the undertaking preventive measures to control exposure at the workplace and also periodic medical examination is highly recommended.
\end{abstract}

Keywords: Lead exposure, kidneys, Serum uric acid, Serum creatinine, Blood ur 


\section{Introduction}

Lead is regarded as a potent occupational toxin and its toxicological manifestations are well known (Flora et al, 2012). The most common exposure to lead among adults is occupational (Hettmansberger and Mycyk, 2002). Lead poisoning has become the most common disease of environmental origin and is still increasing very rapidly in developing countries (Koset, 2005). The risk of lead poisoning is high after inhalation or ingestion of lead in soluble and absorbable forms of fumes, particulates and glaze composed of lead oxides (Hettmansberger and Mycyk, 2002). Recent research has demonstrated that clinical or subclinical toxic effects can occur below the limit of $50 \mu \mathrm{g} / \mathrm{dl}$ in the whole blood (Tak et al, 2008).Blood lead level determination has presently been accepted as the most reliable biomarker (Barbosa et al, 2005).

Lead poisoning affects multiple body organs. Neurological and gastro-intestinal manifestations are predominant in lead poisoning. Chronic exposure leads to loss of short term memory, inability to concentrate, increased excitability, depressive mood, paresthesia of extremities, generalized abdominal pain and nausea (Pearce, 2007). Patients may also complain of headaches, weakness, myalgia, anemia and lead line which are common signs in chronic lead poisoning (Malekirad et al, 2010).

Lead exposure increases the risk for adverse renal outcomes. Lead has been reported to cause nephrotoxicity by several mechanisms. Lead poisoning may cause tubular atrophy and interstitial fibrosis of the kidneys (Karimooy et al, 2010).

Hyperuricemia resulting from impaired tubular function has been identified as a significant promoter of lead nephropathy. Hyperuricemia can mediate both hypertension and kidney injury (Johnson et al, 2003).

Weaver et al, 2000 detected that there was an association between lead exposure in current and former lead workers and adverse renal function outcomes.

More recently, associations between various measures of lead dose and serum uric acid (urate) levels have been reported in studies of occupationally exposed populations (Wang et al, 2002). 
Data from another work suggest that lead has an adverse effect on renal function in the moderate dose range, particularly in older workers (Weaver et al, 2003).

The objective of this research was to study the effect of lead on renal function in exposed workers and its relation with clinical symptoms in those workers.

\section{Aim of Work}

To study the association between blood lead level and some renal and clinical parameters among workers exposed to lead.

\section{Materials and Methods}

The study included 120 male workers exposed to lead for at least 5 years, free from hypertension, diabetes and history of previous renal disease and reporting no history of diseases treated with analgesics. All workers are working as galvanizing painters. They were recruited during their periodic medical examination for measuring blood lead levels (BLL) and further investigations was done for them in the form of serum creatinine, serum uric acid and blood urea.

A structured questionnaire was used to collect data regarding age, job duration, some personal habits, smoking history, presence or absence of certain symptoms related to lead toxicity.

The study subjects were divided into two groups; Group1: those with blood lead level (BLL) less than $20 \mu \mathrm{g} /$ dl and Group2: those with $20 \mu \mathrm{g} / \mathrm{dl}$ or higher levels of BLL. This division was based on the mean blood lead of the current work which was 20.55 \pm 5.90 and this classification was also similar to that of Yalemsew et al., 2012 in their classification of exposed workers.

Sample size calculation: Based on previous studies, the following assumptions were used to calculate sample size: the difference in the mean value of uric acid $=0.7, \mathrm{SD}$ of group $1=$ $1.1, \mathrm{SD}$ of group2=1.1, significant value of 0.05 (alpha error) and power $=90 \%$. The sample size of 106 persons (53 workers in each group) was calculated. The actual sample size in the study was 63 workers in group 1 and 57 workers in group 2.

Venous blood samples (4 $\mathrm{ml}$ each) were collected using carefully labelled vacutainer tubes containing $7.2 \mathrm{mg}$ $\mathrm{K}_{2}$ EDTAby qualified medical laboratory professional. Blood specimen collection was carried out using separate sterilized 
needles and gloves for each individual. The samples were sent to laboratory unit at the faculty of Medicine, Ain Shams University for analysis of blood lead level, serum creatinine, serum uric acid and serum urea.

\section{Ethical consideration}

The purpose of the study was clearly explained to the study participants and oral consent was obtained from each of the participating individuals. Confidentiality of data and a copy of lab results were delivered to each subject.

\section{Results:}

Table (1): Comparison between study groups as regards marital status, smoking history, job nature and some behavioral habits.

\begin{tabular}{|c|c|c|c|c|}
\hline & $\begin{array}{c}\text { Group 1 } \\
\text { BLL } \\
(<20 \mu \mathrm{g} / \mathrm{dl}) \\
\mathrm{N}^{\mathrm{o}}=\mathbf{6 3}\end{array}$ & $\begin{array}{c}\text { Group } 2 \\
\text { BLL } \\
(\geq 20 \mu \mathrm{g} / \mathrm{dl}) \\
\mathrm{N}^{0}=\mathbf{5 7}\end{array}$ & $\begin{array}{l}\text { Statistical } \\
\text { test }\end{array}$ & $P$ value \\
\hline $\begin{array}{l}\text { Age (years) } \\
\text { mean } \pm \text { SD }\end{array}$ & $44.71 \pm 5.67$ & $42.70 \pm 6.66$ & $\mathrm{t}$ test $=1.787$ & 0.077 \\
\hline $\begin{array}{l}\text { Work duration (years) } \\
\text { mean } \pm \text { SD }\end{array}$ & $12.85 \pm 5.38$ & $13.12 \pm 4.14$ & $\mathrm{t}$ test $=0.301$ & 0.764 \\
\hline $\begin{array}{l}\text { Marital status } \\
\text { Married no (\%) }\end{array}$ & $50(79.4)$ & $47(82.5)$ & $\mathrm{X}^{2}$ test $=0.185$ & 0.667 \\
\hline $\begin{array}{l}\text { Tobacco Smoking } \\
\text { Yes: no }(\%)\end{array}$ & $41(53.2)$ & $36(46.8)$ & $\mathrm{X}^{2}$ test $=0.048$ & 0.826 \\
\hline $\begin{array}{l}\text { Eat at the workplace } \\
\text { Yes: no }(\%)\end{array}$ & $40(63.5)$ & $41(71.9)$ & $\mathrm{X}^{2}$ test $=0.971$ & 0.324 \\
\hline $\begin{array}{l}\text { Wash hands before eating } \\
\text { Yes: no }(\%)\end{array}$ & 47 (74.6) & $32(56.1)$ & $\mathrm{X}^{2}$ test $=4.535$ & 0.033 \\
\hline $\begin{array}{l}\text { Wear personal protective } \\
\text { devices } \\
\text { Yes: no }(\%)\end{array}$ & $10(15.9)$ & $11(19.3)$ & $\mathrm{X}^{2}$ test $=0.243$ & 0.622 \\
\hline
\end{tabular}


There was no significant difference between the two groups as regards marital status, tobacco smoking. Regarding the work habits, there was a no significant difference between the two groups as regards eating at the workplace and wearing personal protective devices. The percentage of workers with blood lead level less than $20 \mu \mathrm{g} / \mathrm{dl}$ reporting washing hands before eating was significantly higher than the percentage of workers with blood lead level more than $20 \mu \mathrm{g} / \mathrm{dl}$ giving the same history.

Table (2): relationship between blood lead level and presenting symptoms of participants:

\begin{tabular}{|c|c|c|c|c|}
\hline & $\begin{array}{c}\text { Group } 1 \\
\text { BLL }(<20 \mu \mathrm{g} / \mathrm{dl}) \\
\text { Yes: frequency }(\%)\end{array}$ & $\begin{array}{c}\text { Group } 2 \\
\text { BLL }(\geq 20 \mu \mathrm{g} / \mathrm{dl}) \\
\text { Yes: frequency }(\%)\end{array}$ & $X^{2}$ test & $P$ value \\
\hline Abdominal pains & $27(42.9)$ & $41(71.9)$ & 10.300 & $0.001 *$ \\
\hline Tremors & $23(36.5)$ & $34(59.6)$ & 6.426 & $0.011^{*}$ \\
\hline $\begin{array}{l}\text { Tingling and } \\
\text { numbness }\end{array}$ & $24(38.1)$ & $45(78.9)$ & 20.437 & $<0.001 *$ \\
\hline Constipation & $11(17.5)$ & $4(7)$ & 2.984 & $0.102 * *$ \\
\hline $\begin{array}{l}\text { Difficulty in } \\
\text { sleeping }\end{array}$ & $19(30.2)$ & $25(43.9)$ & 2.419 & 0.120 \\
\hline Weight loss & $20(31.7)$ & $24(42.1)$ & 1.383 & 0.240 \\
\hline Headache & $18(28.6)$ & $19(33.3)$ & 0.318 & 0.573 \\
\hline
\end{tabular}

*: Significant

**: using Fisher Exact test

The percentage of those with blood lead level $\geq 20 \mu \mathrm{g} / \mathrm{dl}$ presenting with abdominal pain, tremors, tingling in extremities was significantly higher than the percentage of those with blood lead level $<20 \mu \mathrm{g} / \mathrm{dl}$. 
Table (3): Comparison between the two groups for serum creatinine, serum uric acid, and serum urea.

\begin{tabular}{|l|c|c|c|c|}
\hline & $\begin{array}{c}\text { Group 1 } \\
\text { BLL }(<\mathbf{2 0} \boldsymbol{\mu g} / \mathbf{d l}) \\
(\mathbf{m e a n} \pm \mathbf{S D})\end{array}$ & $\begin{array}{c}\text { Group 2 } \\
\text { BLL }(\mathbf{2 0} \boldsymbol{\mu g} / \mathbf{d l}) \\
(\mathbf{m e a n} \mathbf{~ S D})\end{array}$ & t-test & P value \\
\hline $\begin{array}{l}\text { Serum creatinine } \\
(\mathbf{0 . 2 - 1 . 2})\end{array}$ & $0.72 \pm 0.18$ & $0.69 \pm 0.16$ & 0.838 & 0.404 \\
\hline $\begin{array}{l}\text { Serum uric acid } \\
(\mathbf{3 . 7 - 7})\end{array}$ & $4.69 \pm 0.91$ & $5.68 \pm 1.36$ & 4.710 & $0.000^{*}$ \\
\hline $\begin{array}{l}\text { Serum urea } \\
(\mathbf{1 0 - 4 5})\end{array}$ & $29.49 \pm 9.24$ & $30.45 \pm 9.31$ & 0.568 & 0.571 \\
\hline
\end{tabular}

*: Significant

The workers with blood lead level $\geq 20 \mu \mathrm{g} / \mathrm{dl}$ had a significantly higher serum uric acid (Mean \pm SD) than those with blood lead level $<20 \mu \mathrm{g} / \mathrm{dl}$ while there were insignificant differences for serum creatinine and serum urea.

Table (4): Partial correlation between blood lead level and serum creatinine, uric acid and blood urea:

\begin{tabular}{|l|c|c|c|c|c|c|}
\hline \multirow{2}{*}{} & \multicolumn{2}{|c|}{ Uric acid } & \multicolumn{2}{c|}{ Blood urea } & \multicolumn{2}{c|}{ Serum creatinine } \\
\cline { 2 - 7 } & Partial r & P value & Partial r & P value & Partial r & P value \\
\hline Blood lead level & 0.533 & 0.000 & 0.148 & 0.109 & 0.146 & 0.114 \\
\hline
\end{tabular}

Table (4) and figure (1) show that there was a significant positive correlation between blood lead level and serum uric acid even after adjustment for age and work duration. (Partial $\mathrm{r}=0.533, \mathrm{p}<0.001$ ). The partial correlations between blood lead level and serum creatinine and blood urea showed positively insignificant correlation. 


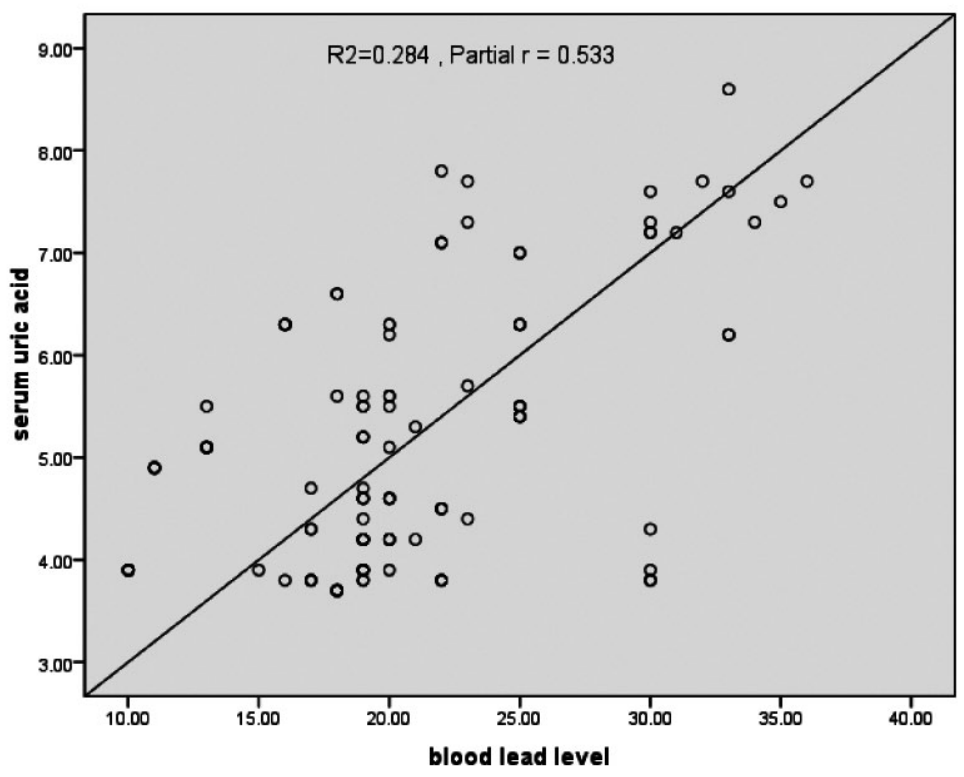

Figure (1): Scatter diagram between blood lead level and serum uric acid

\section{Discussion}

The participants of the current study were divided into two groups according to their blood lead level where group 1 included those with blood lead less than $20 \mu \mathrm{g} / \mathrm{dl}$ and group 2 included those with blood lead equals to and more than $20 \mu \mathrm{g} / \mathrm{dl}$. The two groups showed no significant difference as regards mean age and work duration, marital status and smoking history.

Regarding some habits at the workplace, there was no significant difference between the two groups regarding wearing personal protective devices and eating at the workplace. However, the percentage of workers from group one reporting washing hands before eating was significantly higher than the corresponding percentage of workers from group two. Personal hygienic behavior and life habits such as eating, drinking and smoking in different workplaces are also thought to be important in determining the toxicity of lead (Lormphongs et al, 2003). Several studies have found that due to lack of awareness about their exposure, workers usually eat, smoke or drink while at work and such workplace practices may aggravate their exposure 
(Pala et al, 2009), (Grandjean et al, 1981).

Abdominal pain, tremors and tingling in the extremities were presentations significantly associated with higher blood lead levels. In another study, the main clinical findings were the presence of lead line, peripheral neuropathy of the upper extremities and abdominal tenderness. The subjective findings were mainly attributed to the central nervous system and included loss of memory, drowsiness and headache (Balali-Mood et al, 2010). It is known from literature that neurological and gastrointestinal manifestations are predominant in lead poisoning, chronic exposure among adults leads to loss of short term memory, inability to concentrate, paresthesia of extremities, generalized abdominal pain and nausea (Patrick, 2006). In one study, comparison of the prevalence of non specific symptoms as depression, wrist drop, tingling and numbness in the fingers and hands, nausea between the occupationally exposed individuals with blood lead levels less than $20 \mu \mathrm{g} /$ $\mathrm{dl}$ with that of the controls has revealed that there is a significantly greater prevalence of most of the symptoms among exposed workers (Yalemsew et $\mathrm{al}, 2012)$
Our study showed that the level of serum uric acid was significantly higher among workers with increased blood lead levels. This agrees with the findings of other studies (Lin et al, 2001-Lin et al, 2002-Alasia et al, 2010). Hyperuricemia associated with lead toxicity occurs in both acute and chronic lead nephropathy and is thought to be due to isolated proximal tubular defects (Loghman-Adham, 1997- Gonick, 2008). The significant association between elevated blood lead level and serum uric acid remained even after adjustment for age and work duration by partial correlation. Other studies have detected significant correlations between blood lead level less than 10 $\mu \mathrm{g} / \mathrm{dl}$ and elevations in serum creatinine (Brady et al, 2007)

\section{Conclusion}

People with occupational lead exposure are at risk of developing hyperuricemia which is an initial step in renal impairment. In view of the higher risk of lead exposure in developing countries and the poor regulation of occupational lead exposure, it is recommended that the routine screening of occupational lead exposure risk groups for any increase in serum uric acid or disturbed renal function tests 
be undertaken as part of measures to control and prevent lead induced chronic kidney disease.

\section{Conflict of interest: None declared}

\section{Limitations:}

Our study groups were only limited to galvanic painters while other occupations with lead exposure were not included in the study.

\section{References}

1. Alasia AA, Emem-Chioma PC, Wokoma FS (2010): Association of lead exposure, serum uric acid and parameters of renal function in Nigerian lead exposed workers. IJOEM; 1(4): 182-190.

2. Balali -Mood M, Shademanfar S, Rastegar Moghadam J , Afshari R, Namaei Ghassemi M, Allah Nemati H, Keramati MR, Neghabian J, Baladi-Mood B, Zare G (2010) : Occupational lead poisoning in workers of traditional tile factories in Mashhad. "Northeast of Iran. Int J Occup Environ Med; 1(1): 29-38.

3. Barbosa F, Tanus - Santos JE, Gerlach RF, Parsons PJ (2005): A critical review of biomarkers used for monitoring human exposure to lead: advantages, limitations and future needs." Environ Health Perspect; 113(12): 1669-1674.

4. Brady HR, Brenner BM, Clarkson MR, etal. (2007) : Acute kidney injury. In: Brenner BM, ed. Brenner and Rector's The Kidney. 8th ed. Philadelphia: WB Saunders: 943-975.

5. Flora G, Gupta D, Tiwari A (2012): Toxicity of lead: a review with recent updates. Interdiscip Toxicol; 5(2): 47-58.

6. Gonick HC (2008): Nephrotoxicity of cadmium and lead. Indian J Med Res; 128:335-52.
7. Grandjean P, Hollnagel H, Olsen NB (1981): Occupationally related lead exposure in the general population. Scan J Work Environ Health, 7:298-301.

8. Hettmansberger TL and Mycyk MB (2002): Lead poisoning presents a difficult diagnosis. Am Fam Physician; 66 (10):1839-40.

9. Johnson RJ, Kang D, Feig D, et al (2003): Is there a pathologic role for uric acid in hypertension and cardiovascular and renal disease? Hypertension; 41: 1183-90.

10. Karimooy HN, Mood MB, Hosseini M, Shadmanfar S (2010): Effects of occupational lead exposure on renal and nervous system of workers of traditional tile factories in Mashhad (northeast of Iran). Toxicol Ind Health 2010; 26: 633-8.

11. Koset MJ (2005): Lead. In: Brent J, Wallace KL, Burkhart KK, Phillips SD, Donovan JW, eds. Critical Care Toxicology. Philadelphia: ElSevier- Mosby: 821-836.

12. Lin JL, Tan DT, Ho HH, Yc CC (2002): Environmental lead exposure and urate excretion in the general population. Am J Med; 113(7): 563-8.

13. Lin JL, Yu CC, Lin - Tan DT, Ho HH (2001): Lead chelation therapy and urate excretion in patients with chronic renal disease and gout. Kidney Int; 60(1):266-71.

14. Loghman-Adham M (1997) : Renal effects of environmental and occupational lead exposure." Environ Health Perspect; 105(9): 928-38.

15. Lormphongs S, Miyashita K, Morioka I, Chaikittiporn $\mathrm{Ch}$, Miyai $\mathrm{N}$, Yamamoto $\mathrm{H}$ (2003): Lead exposure and blood lead level of workers in a battery manufacturing plant in Thailand. Ind Health; 41(4): 348-353.

16. Malekirad AA, Oryan S, Fani A, Babapor V, Hashemi M, Baeeri M, et al. (2010) : Study on clinical and biochemical toxicity biomarkers in a zinc-lead mine workers. Toxicol Ind Health; 26: 331-7. 
17. Pala K, Turkkan A, Gucer S, Osman E, Aytekin H (2009) : Occupational lead exposure: blood lead levels of apprentices in Bursa, Turkey. Ind Health, 47:97-012

18. Patrick L (2006): Lead toxicity, a review of the literature. Part one: exposure evaluation and treatment. Altern Med Rev; 11:2-22.

19. Pearce JM (2007): Burton line in lead poisoning. Eur Neurol; 57:118-9.

20. Tak SW, Roscoe RJ, Alarcon W, Ju J, Sestito JP, Sussell AL, et al. (2008): Characteristics of US workers whose blood lead levels trigger the medical removal protection provision and conformity with biological monitoring requirements 2003-2005. Am J Ind Med; 51(9): 691-700.

21. Wang VS, Lee MT, Chiou JY, Guu CF, Wu CC, Wu TN, et al. (2002): Relationship between blood lead level and renal function in lead battery workers. Int Arch Occup Environ Health; 75: 569-575.

22. Weaver VM, Buckley T, Groopman JD (2000): Lack of specificity of trans, transmuconic acid as a benzene biomarker after ingestion of sorbic acid preserved foods. Cancer Epidemiol Biomarkers Prev; 9:749-755.

23. Weaver VM, Lee BK, Ahn K-D, lee G-S, Todd AC, Stewart WF, Wen J, Simon DJ, Parsons PJ, Schwartz BS (2003): Associations of lead biomarkers with renal function in Korean lead workers. Occup Environ Med; 60(8):551-62.

24. Yalemsew A, Argaw A and Dejene A (2012): Occupational lead exposure among automotive garage workers- a case study for Jimma town, Ethiopia. J Occup Med Toxicol 2012; 7:15 doi: 10.1186/1745-6673-7-15. 